\title{
Effect of oyster shell powder on nitrogen releases from contaminated marine sediment
}

\author{
Md Akhte Khirul ${ }^{1}$, Beom-Geun Kim¹, Daechul $\mathrm{Cho}^{2}$, Gilsun Yoo $^{2}$, Sung-Hyun Kwon ${ }^{{ }^{\dagger}}$ \\ ${ }^{1}$ Department of Ocean System Engineering, College of Marine Science, Gyeongsang National University, Tongyeong 53064, Republic of Korea \\ ${ }^{2}$ Department of Energy and Environmental Engineering, Soonchunhyang University, Asan 31538, Republic of Korea \\ ${ }^{3}$ Department of Marine Environmental Engineering, College of Marine Science, Engineering Research Institute (ERI), Gyeongsang National University, \\ Tongyeong 53064, Republic of Korea
}

\begin{abstract}
Nitrogen flux release from organically enriched sediments into overlying water, which may have significantly influence on water quality and increasing continuous eutrophication. The purpose of this study is to evaluate the remediation efficiency of oyster shell powder and its treated product into organically enriched sediment in terms of nitrogen flux, organic matter, chlorophyll-a, $\mathrm{pH}$ and dissolved oxygen (DO). The TOSP was mainly composed of $\mathrm{CaO} 2$. The application of TOSP into the sediment has increased the $\mathrm{pH}, \mathrm{DO}$ and significantly decreased the concentrations of $\mathrm{NH}_{4}{ }^{+}-\mathrm{N}$ and T-N compared to other basins. On the other hand, nitrate was enriched with the addition of treated oyster powder, an oxygen releasing compound on both phases. Furthermore, chlorophyll-a was found to be increasing with time in the control basin meanwhile it dropped drastically with the addition of TOSP, which implied on the repression of algal growth owing to blockage of nitrogen source migrating from the sediment. This study has shown that the TOSP was effective to improve sediment-water quality, diminish eutrophication and control harmful algae blooms in a marine environment. Therefore, it is a good reference as an effective environmental remediation agent.
\end{abstract}

Keywords: Eutrophication, Marine sediment, Nitrification, Oxygen releasing compounds, Oyster shell powder

\section{Introduction}

Eutrophication is one of the serious problems in the marine environment which can lead to a large scale growth of algae. This phenomenon in the coastal waters can occur by the input of various waste sources which is derived mainly from industrial wastewater, agricultural, and aquaculture activities (e.g., fish and oyster farm), etc. Eutrophication is an enrichment of water with nutrients, primarily phosphorus, nitrogen, and much amount of organic matter, which stimulates primary production [1]. Nitrogen is an essential nutrient for biological productivity and therefore plays an important role in the marine environment. The eutrophication problem suggests that the excess nutrient input enshroud the ability of bodies of water to self-purify, thereby changing the nature of the ecosystem and leading to phytoplankton blooms [2-4]. The initial source of eutrophication causes an increase in chlorophyll-a.

This is an Open Access article distributed under the terms of the Creative Commons Attribution Non-Commercial License (http://creativecommons.org/licenses/by-nc/3.0/) which permits unrestricted non-commercial use, distribution, and reproduction in any medium, provided the original work is properly cited.

Copyright (C) 2020 Korean Society of Environmental Engineers
It is a common indicator for the presence of algae and often considered as the dominant factor or assessing eutrophication [5]. Resuspension of particulate matter can raise primary production because of the intrusion of the sediment pore water rich with nutrients into the bottom layer and consequently into the whole water column from the sediments [6]. Over time, nutrients could also prolong in the sediment and make the potential for an internal load that can be recycled back into the water column under different environmental conditions [7]. The concentration of nitrogen in the overlying water of marine environments, which comes from sediment, is regarded as a major component of the internal source. Such nitrogen release from bottom sediment may have a significant impact on water quality and may result in continued eutrophication, which might give a negative impact on economic and social development.

The southeast coastal area in South Korea is one of the most productive oyster-farming waters in the world, with shellfish-farm-

\author{
Received November 10, 2018 Accepted March 15, 2019 \\ ${ }^{\dagger}$ Corresponding author \\ Email: shkwon@gnu.ac.kr \\ Tel: +82-55-772-9132 Fax: +82-55-772-9139 \\ ORCID: 0000-0001-5803-2003
}


ing constituting a large part of the regional economy. According to the ministry of oceans and fisheries in Korea, produce 290,000 tons of oyster shells every year. Some discarded oyster shells are substituted for limestones in fertilizers and feed for chickens, while remain is left piling up in the seashore of south coast area which becomes a serious environmental issue [8]. While several studies have been published on the applications of waste oyster shells as a soil conditioner, construction material, catalyst, and filtering medium, there is little information on the application of the oyster shell powder to remediating contaminated sediments [9-12]. Since the coastal sediments are rich in organic matter, using recycled oyster shell powder to reduce nutrients from the sediments will be compatible with the objectives of recycling and environmental restoration.

Recycled oyster shell powder is supposed to slowly decompose in contact with water to result in the release of its oxygen. The released oxygen can promote contaminant's oxidation and enhance in situ aerobic microbial degradation [13, 14]. These compounds can build up an aerobic condition in mid of the sediment to stimulate the activity of aerobic bacteria. Oxygenation is an important factor for remediation [15]. It is reported that calcium peroxide reacts with water and produces calcium hydroxide to raise $\mathrm{pH}$ and to form an oxic environment over the sediment with generated oxygen [16]. In addition, the reduction of nutrients release flux from the organically enriched sediment should be regarded as an urgent agendum to be under control.

The main purpose of this study is to: (1) evaluate the performance of raw oyster shell powder (ROSP) and treated oyster shell powder (TOSP) application to organically enriched coastal sediment and water to diminish eutrophication; (2) investigate the influence of $\mathrm{pH}$, dissolved oxygen (DO), chlorophyll-a, and chemical oxygen demand (COD) on nitrogen nutrients (ammonium nitrogen, nitrate nitrogen and nitrite nitrogen) release from sediment by using oyster shell powder. Each experiment was designated not to contaminate water during sampling by using a separate basin. This study will provide helpful information for the practices of endogenic release presumption and for the improvement of the marine environment proximity to reduce the release intensity.

\section{Materials and Methods}

\subsection{Sample Collection and Study Area}

Marine sediment and water samples were collected near a marine college in the city of Tongyeong ( $\left.34^{\circ} 50^{\prime} 28.5^{\prime \prime} \mathrm{N} 128^{\circ} 28^{\prime} 16.4^{\prime \prime} \mathrm{E}\right)$, in the southeast coast of South Korea. The sampling site was chosen by its malicious odor and water due to multiple pollution sources such as waste dumping and fishing activities, especially by aquaculture activities. The sediment sample was collected from around $10 \mathrm{~m}$ below of water level through a stainless steel grab sampler at a depth of 0-20 cm which was quickly packed in airtight cleaned polythene bags and transported to the laboratory for storage at $-20^{\circ} \mathrm{C}$ until analysis. The sampler was cleaned with deionized water before use to avoid unnecessary contamination. Seawater was collected from the same site. A sufficient amount of seawater was collected as the sample from the water column at a depth of $0.5 \mathrm{~m}$ by a water sampler. To make sure of the homogeneity, sampling was restricted within a relatively small area. All sediment samples were homogenized before use.

\subsection{Preparation of TOSP}

The main chemical composition of ROSP is $92.08 \%$ of calcium carbonate $\left(\mathrm{CaCO}_{3}\right)$ [17]. ROSP was calcined at ambient air condition inside an electric furnace at a constant temperature of $900^{\circ} \mathrm{C}$ for $1 \mathrm{~h}$. After that heat treatment, it is mixed with some calcium carbonate containing $\mathrm{CO}_{2}$ portion and most of crystalline $\mathrm{CaO}$ [18]. The crystalline $\mathrm{CaO}$ turned to be a hydrated form of calcite, namely $\left[\mathrm{Ca}(\mathrm{OH})_{2}\right]$. Then calcium hydroxide was reacted with hydrogen peroxide to produce calcium peroxide $\left(\mathrm{CaO}_{2}\right)$, which is a so-called TOSP, an oxygen releasing compound. Involved reactions are shown as follows:

$$
\begin{gathered}
\mathrm{CaCO}_{3} \stackrel{\text { Calcination }}{\longrightarrow} \mathrm{CaO}+\mathrm{CO}_{2} \\
\mathrm{CaO}+\mathrm{H}_{2} \mathrm{O} \longrightarrow \mathrm{Ca}(\mathrm{OH})_{2} \\
\mathrm{Ca}(\mathrm{OH})_{2}+\mathrm{H}_{2} \mathrm{O}_{2} \longrightarrow \mathrm{CaO}_{2}+2 \mathrm{H}_{2} \mathrm{O}
\end{gathered}
$$

\subsection{Basin Incubation}

In this experimental basin, 300 gm of sediment and $1 \mathrm{~L}$ of filtered seawater were added to 2-L graduated basin. Before added water, the applied of ROSP and TOSP dosage were $0.5 \%(\mathrm{w} / \mathrm{w})$ mixed to be completely homogenized in the sediment per basin. While the other basin was filled by the same quantity of natural sediment (treated as control). Then one liter of filtered seawater was added to each basin carefully to avoid disturbing the sediment. Five replicated basins were established of each treatment for the experiments of the $20 \mathrm{~d}$ incubation period. All basins then were covered with aluminum foil and placed in an incubator where an alternative change (12 h light and $12 \mathrm{~h}$ darkness in a day) was applied. Incubation temperature was set at $22^{\circ} \mathrm{C}$ all the time, which would simulate the field condition including its microbial distribution. Samples were taken for analysis on the days of 0, 5, 10, 15 and 20.

\subsection{Analyses of Physicochemical and Chemical Characteristics}

Before measuring the physicochemical parameters, the sediment and overlying water were separated from the basin and the sediment was homogenized. The parameters of overlying water and sediment, including $\mathrm{pH}$ and oxidation-reduction potential (ORP) were measured at each basin using the multi-parameter meters (Orion 3 star, USA), additionally DO with temperature was measured by DO meter (YSI 550A, USA).

The water samples were carefully withdrawn and filtered through a glass microfiber filter paper (GF/C, What man, UK) before analyses. The sediment samples were collected to three centrifuge tubes, approximately 65-70 g from each basin, then centrifuged at 2,000 rpm for $20 \mathrm{~min}$ to collect about $10 \mathrm{~mL}$ of supernatant pore water. This pore water was used to dilute samples within the detective range. The COD was analyzed by the oxidizing agent of potassium permanganate followed by the iodometric titration method. The chlorophyll-a concentration was determined with spectrometric absorbance after acetone extraction from water 
samples. The concentration of ammonium nitrogen $\left(\mathrm{NH}_{4}{ }^{+}-\mathrm{N}\right)$ was determined by indophenol blue method, and total nitrogen (T-N) was measured by oxidizing the sample with potassium persulfate. Nitrate $\left(\mathrm{NO}_{3}{ }^{-} \mathrm{N}\right)$ and nitrite $\left(\mathrm{NO}_{2}{ }^{-}-\mathrm{N}\right)$ concentrations were measured by through a cadmium-copper $(\mathrm{Cd}-\mathrm{Cu})$ column reduction and $\mathrm{N}$-(1-naphthyl)-ethylenediamine adsorption spectrophotometry, respectively. For the examination of seawater and sediments were analyzed by standard methods of the Ministry of Oceans and Fisheries, South Korea, 2013 [19]. All spectroscopic analyses were analyzed by UV Mini-1240 spectrophotometer (Shimadzu Corporation, Kyoto, Japan). All samples were analyzed in triplets and averaged data were used.

\subsection{Nutrients Release Experiments}

Nutrients releases at the water and sediment interface in a basin were investigated in terms of a flux rate. Nutrients release rates were determined according to Hieltjes and Lijklema [20] as proposed. The rates can be calculated under an assumption that the concentrations of species $i$ depend only on flow-in, flow-out, and horizontal surface area over the sediment and with the material balance over the reactor [21]. The suggested nutrient release rate is as follows:

$$
r=\frac{\left[V\left(C_{n}-C_{o}\right)+\sum V_{n}\left(C_{n-1}-C_{a}\right)\right]}{A t}
$$

Where

$r$ is releases rate $\left(\mathrm{mg} / \mathrm{m}^{2} / \mathrm{d}\right)$.

$V$ is the volume of overlying water $\left(\mathrm{m}^{3}\right)$.

$C_{n}$ is the concentration of nutrient at the $\mathrm{n}^{\text {th }}$ time $(\mathrm{mg} / \mathrm{L})$.

$C_{0}$ is the initial concentration of nutrients $(\mathrm{mg} / \mathrm{L})$.

$V_{n}$ is the sampling water volume each time $\left(\mathrm{m}^{3}\right)$.

$C_{a}$ is the concentration of nutrients after replenishing overlying water.

$n$ is the number of sampling.

$A$ is the water interfacing area of the sediment $\left(\mathrm{m}^{2}\right)$.

$t$ is the averaged sampling interval (d).

\section{Results and Discussion}

\subsection{Effect of Oyster Shell Powder Treatment on pH in the Overlying Water}

The effect of oyster shell powder on the $\mathrm{pH}$ level of the overlying water was measured during $20 \mathrm{~d}$ of the incubation period (Fig. 1). Potentially addition of ROSP basin, no visible change of the $\mathrm{pH}$ value in the overlying water. Because ROSP main component is $\mathrm{CaCO}_{3}$, which is very low solubility in water. However, with inputs of TOSP was a $\mathrm{pH}$ raise in the early couple of days reflecting an alkaline condition. Some portion of calcium peroxide from TOSP generates hydroxide with the release of oxygen, resulting in higher $\mathrm{pH}$. After $15 \mathrm{~d}$ the uprising of $\mathrm{pH}$ returned to the initial value, reflecting a variety of chemical changes in the system. On the other hand, the control basin $\mathrm{pH}$ value was significantly increased of the overlying water. The $\mathrm{pH}$ rises in the control basin seem partly to owe the consumption of carbon dioxide via

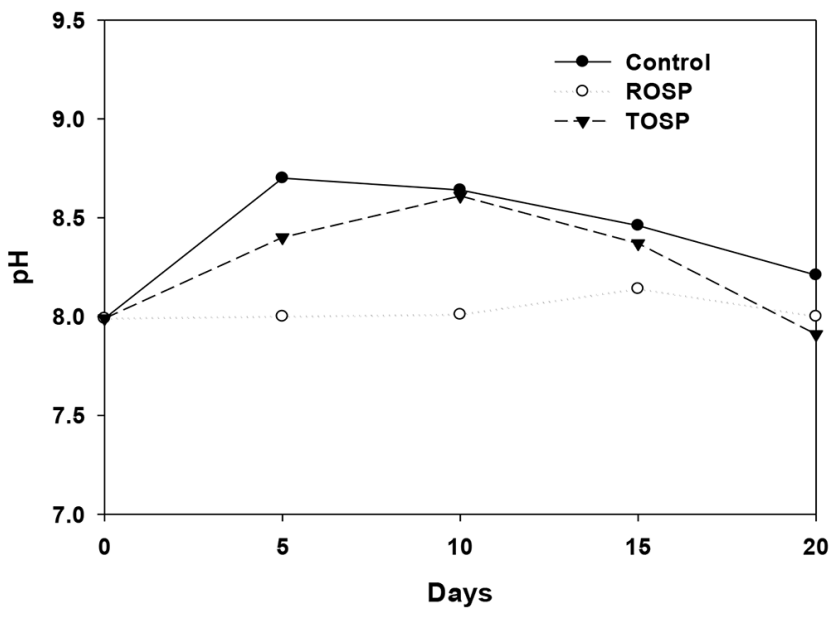

Fig. 1. Change of $\mathrm{pH}$ in the overlying water by addition of ROSP, TOSP $(0.5 \% \mathrm{w} / \mathrm{w})$ and control for $20 \mathrm{~d}$.

photosynthesis. Massive algal photosynthesis is presumed as heavy consumption of $\mathrm{CO}_{2}$, possibly resulting in $\mathrm{pH}$ rise [22]. With an increase in the chlorophyll-a, the consumption of carbon dioxide caused by photosynthesis has increased and subsequently resulted in an increase in $\mathrm{pH}$ value. In the control basin, due to the rapid growth of algae in the overlying water caused by the high concentration of nitrogen released from sediments described later.

\subsection{Effect of Oyster Shell Powder Treatment on Dissolved Oxygen (DO) and Chlorophyll-a in the Overlying Water}

Basically, oxygen enters into the water from two sources by the atmosphere and photosynthesis of algae or plant. The primary source of oxygen in overlying water is from microscopic algae (phytoplankton). Through photosynthesis microbes like phytoplankton, oxygen is released into the water where it dissolves, forming DO. Photosynthesis phases are divided up into light and darkness ones. In this work, the light and dark phases were set as $12 \mathrm{~h}$ each at $22^{\circ} \mathrm{C}$ for $20 \mathrm{~d}$. DO has been changed with time as shown in (Fig. 2). The DO was increased into the overlying water as a result of photosynthesis during the presence of light by the algae in the control basin. The simplified photosynthesis process is represented by the equation:

$$
6 \mathrm{H}_{2} \mathrm{O}+6 \mathrm{CO}_{2} \stackrel{\text { light energy }}{\longrightarrow} 6 \mathrm{O}_{2}+\mathrm{C}_{6} \mathrm{H}_{12} \mathrm{O}_{6}
$$

Which shows that water $\left(\mathrm{H}_{2} \mathrm{O}\right)$ together with carbon dioxide $\left(\mathrm{CO}_{2}\right)$ and energy from the light is transformed into oxygen $\left(\mathrm{O}_{2}\right)$ and organic matter $\left(\mathrm{C}_{6} \mathrm{H}_{12} \mathrm{O}_{6}\right)$.

As expected, the TOSP treatment showed the higher DO value than the other samples, because of its oxygen releasing ability attributed to the oxides portion that tends to transform into free oxygen in case of contact with water. On the other hand, ROSP treated basin DO value no visible change from 0 to $10 \mathrm{~d}$. But after $10 \mathrm{~d}$, DO value slightly increased with algae concentration due to the photosynthesis process. Likewise observed in the $\mathrm{pH}$ changes, DO values in all basins went back to their starting one in 3 weeks except in the TOSP treated 


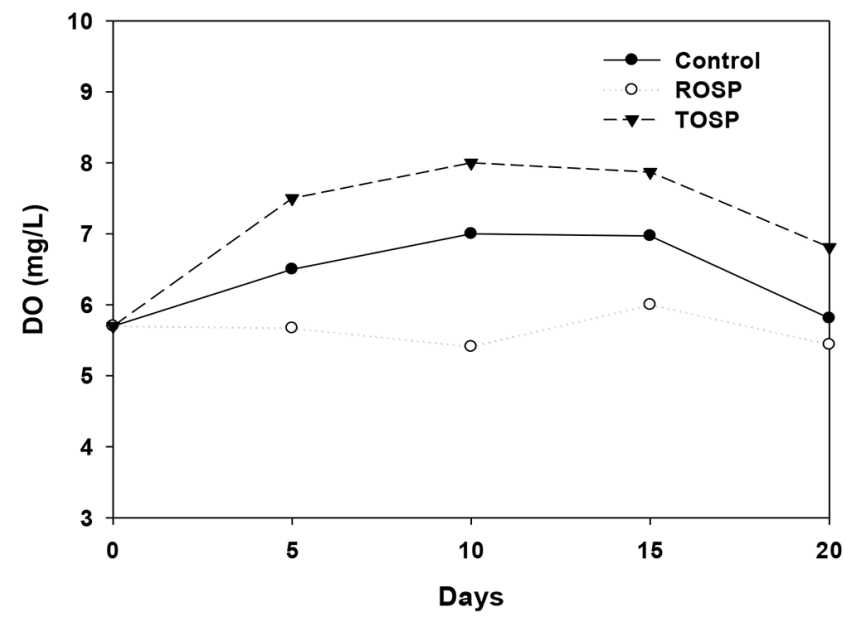

Fig. 2. Change of DO in the overlying water by addition of ROSP, TOSP $(0.5 \% \mathrm{w} / \mathrm{w})$ and control for $20 \mathrm{~d}$.

basin, which meant the prolonged release of oxygen with the treated calcium oxide.

Chlorophyll-a is an important indicator of the presence of algae. The concentration of chlorophyll-a was measured in the overlying water of each basin (Fig. 3). At the beginning, its concentration was $3.45 \mu \mathrm{g} / \mathrm{L}$. That concentration in the control basin kept increasing during the whole incubation time, reaching $130 \mu \mathrm{g} / \mathrm{L}$, namely an active algal growth. In contrast, oyster shell powder treatment in overall suppressed the growth of algae even though TOSP raised chlorophyll-a in early times but maintained its concentration at the lower level until the end of the experiment.

Algal growth is closely related to a variety of environmental parameters for water quality such as total nitrogen, total phosphorus, light intensity, water temperature, $\mathrm{pH}$ and DO [23, 24]. The increase of chlorophyll-a found in the overlying water is in part due to the higher level of nitrogen migrated from the sediment. This matches well with the fact that algal growth could be facilitated in the presence of a high concentration of ammonium which availed distinctly with ROSP treated basin rather than oxygenated nitrogen

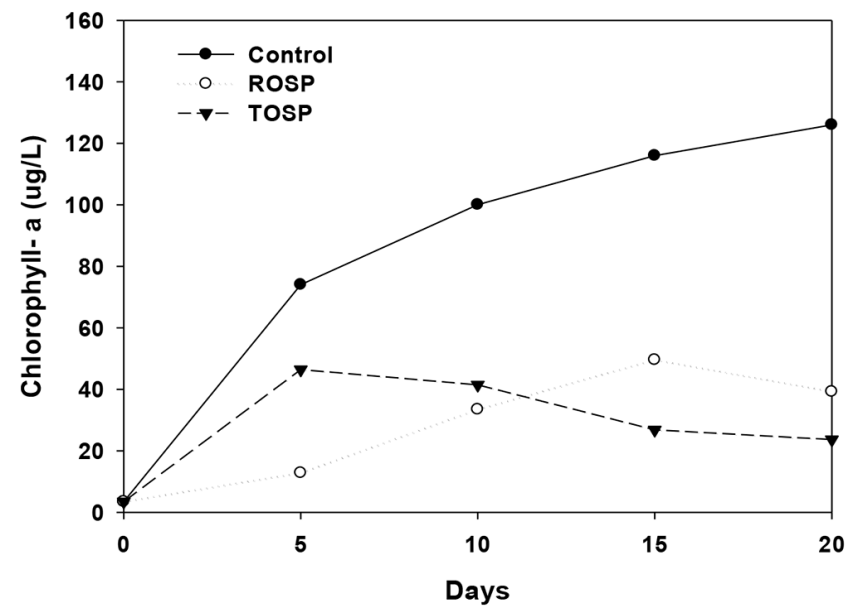

Fig. 3. Change of chlorophyll-a in the overlying water by addition of ROSP, TOSP $(0.5 \% \mathrm{w} / \mathrm{w})$ and control for $20 \mathrm{~d}$. compounds [25]. Algal growth seemed to be coupled with nutritional release into the water as well as the presence of light. As shown in Fig. 3, in the TOSP treated basin, there found an early rise of algal mass. However, the expected decrease in the nutrient release after $5 \mathrm{~d}$ brought in the slowdown of the algal growth. It is also presumed that with an increase in the chlorophyll-a, caused by photosynthesis has increased and subsequently resulted in an increase in $\mathrm{pH}$ value.

\subsection{Effect of Oyster Shell Powder Treatment on Chemical Oxygen Demand (COD) in the Overlying Water}

COD is regarded as an important indicator of the pollution level, representing a present organic substance. As shown in Fig. 4, at the beginning COD value was equally $2.2 \mathrm{mg} / \mathrm{L}$. In the control basin without any OSPs there was a surge of COD due to nutrient transfer from the sediment and probable self-growing organism (algae for instance), and the level seemed to remain the same to the end (or decline slightly probably due to some bioactivity). OSP treatment seemed to maximize the capacity of the porous absorbent so as to minimize COD in the overlying water layer. Additionally, peroxide in the TOSP provided extra oxygen into the water phase for stimulating the biological degradation of carbon-based organic matter existing in the overlying water [23]. Especially in the TOSP treated basin, the COD returned to 2.8 $\mathrm{mg} / \mathrm{L}$, close to $2.2 \mathrm{mg} / \mathrm{L}$ or the initial COD probably due to that combinational activity.

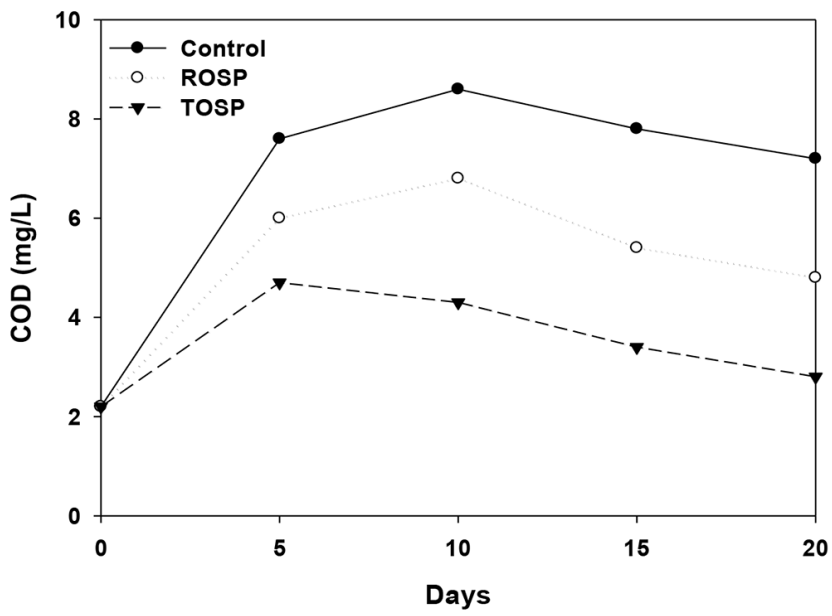

Fig. 4. Change of chemical oxygen demand (COD) in the overlying water by addition of ROSP, TOSP $(0.5 \% \mathrm{w} / \mathrm{w})$ and control for $20 \mathrm{~d}$.

\subsection{Effect of Oyster Shell Powder Treatment on Nitrogenous Nutrients in the Overlying Water and Sediments}

Eutrophication generally produces many derivatives from nitrogen: ammonium nitrogen, nitrate nitrogen, nitrite nitrogen, and other nitrogenous organic matter. Also, it may influence the nitrogen cycle in the sea which is closely linked to the other element cycles like phosphorus, iron, sulfur, and carbon. Nitrogen and nitrogenous compounds are known to be controlled by many factors, for exam- 

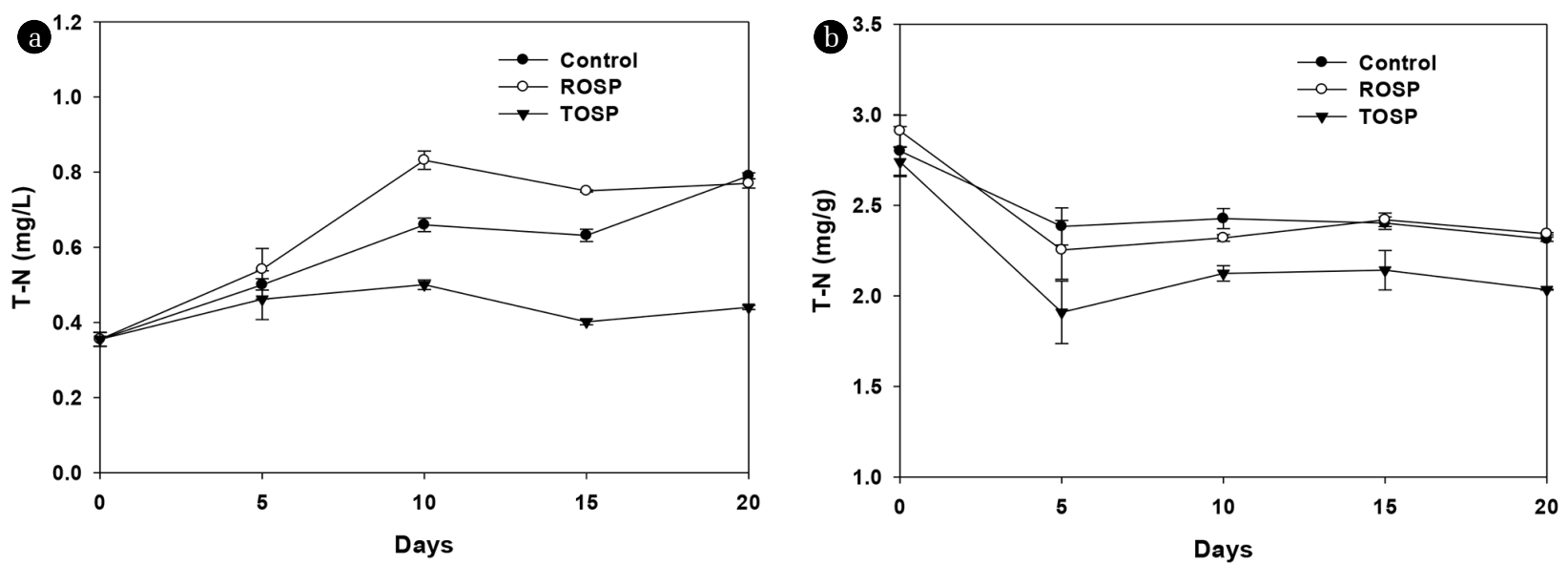

Fig. 5. Change of T-N concentration (a) overlying water (b) sediment by addition of ROSP, TOSP $(0.5 \% \mathrm{w} / \mathrm{w})$ and control for $20 \mathrm{~d}$. Bars represent standard deviation of triplicates.
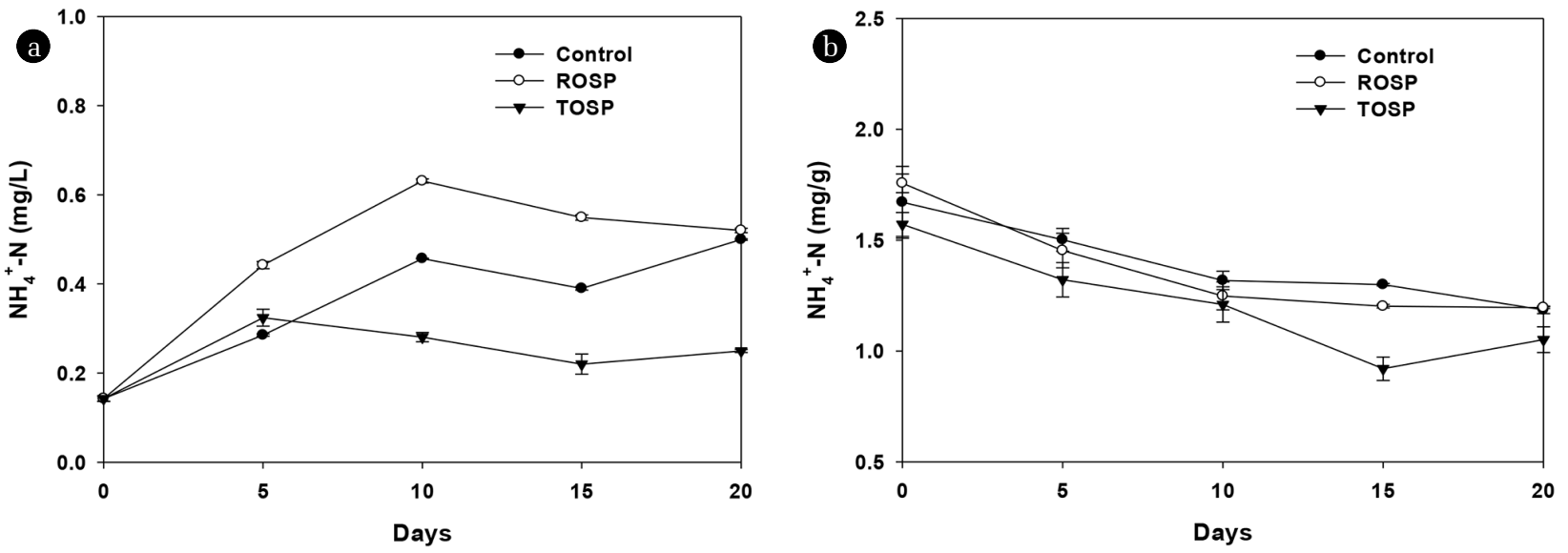

Fig. 6. Change of $\mathrm{NH}_{4}{ }^{+}-\mathrm{N}$ concentration (a) overlying water (b) sediment by addition of ROSP, TOSP $(0.5 \% \mathrm{w} / \mathrm{w})$ and control for $20 \mathrm{~d}$. Bars represent standard deviation of triplicates.

ple, the rate of sedimentation, sediment type, redox condition, amount and type of organic matter, and intensity of mineralization of organic matter in the sediment and water [26]. In this section, the behavior of the essential $\mathrm{N}$-nutrients such as $\mathrm{T}-\mathrm{N}, \mathrm{NH}_{4}{ }^{+}-\mathrm{N}$, $\mathrm{NO}_{3}^{-}-\mathrm{N}$, has been monitored in the experimental basins (Fig. 5-7). OSPs were used in $0.5 \%(\mathrm{w} / \mathrm{w})$ each as described earlier.

T-N concentration in the overlying water was increased with mass transfer of nutrients from the sediments. In the meantime $\mathrm{T}-\mathrm{N}$ in the sediment decreased mainly due to the migration of the nutrients. Comparing T-N concentrations in two compartments, there seems to be an extra loss of T-N, which might happen from some bio \& physicochemical activities in the sediment. For the TOSP basin, excess oxygen introduced from the peroxide should activate locally a microbial augmentation. With ROSP it looks like more nitrogen compound avails in the water phase than as expected when it is compared to the control where a low level of bioactivity was supposed to be going on during the experimental period. But in $20 \mathrm{~d}$ ROSP input eventually did not make any difference with the control probably due to the disappearance of the bioactivity in the control basin. It was interesting to find a big reduction of T-N in early times from 2.74 to $2.03 \mathrm{mg} / \mathrm{g}$ (26\%) in the TOSP treated sediments, which suggested a considerable microbial action through the provision of excess oxygen and/or physical sorption of the porous particles. It was also found that there lasted active migration of the nutrients from the sediment until $10 \mathrm{~d}$ considering the gradual attenuation of the bioactivity.

Ammonium liberation from the sediment has happened in the same way as the T-N case (Fig. 6). Ammonium concentrations in the sediment decreased almost in a linear pattern in all basins. The averaged decreasing rate was comparable to that of T-N. Accordingly, the ammonium behavior was similar to $\mathrm{T}-\mathrm{N}$ in the overlying water. Obviously, the lower amount of ammonium was detected than T-N and then kept at a certain level without any noticeable reduction. This implies no significant evaporation of ammonium into the air out of the alkaline water phase after 10 $\mathrm{d}$ of incubation. With the presence of a sufficient amount of oxygen, some nitrifying bacteria could be populated in order to precede oxidation of ammonium [21]. The algal productivity could be high 

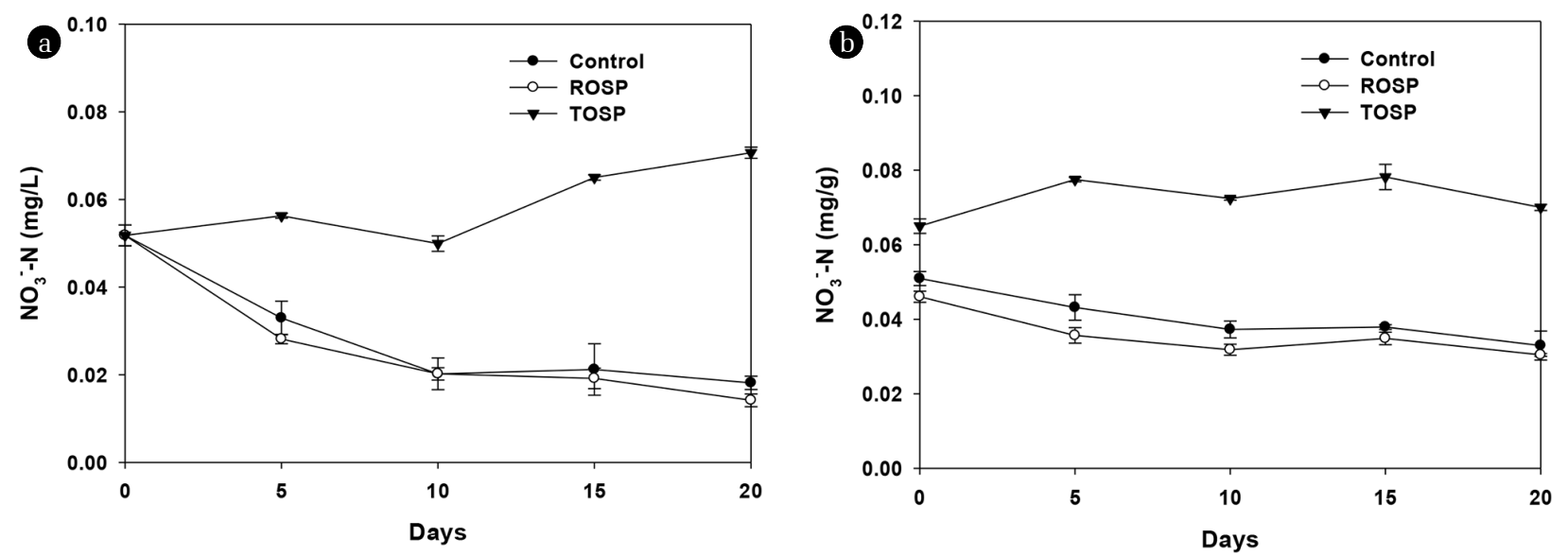

Fig. 7. Change of $\mathrm{NO}_{3}{ }^{-} \mathrm{N}$ concentration (a) overlying water (b) sediment by addition of ROSP, TOSP $(0.5 \% \mathrm{w} / \mathrm{w})$ and control for $20 \mathrm{~d}$. Bars represent standard deviation of triplicates.

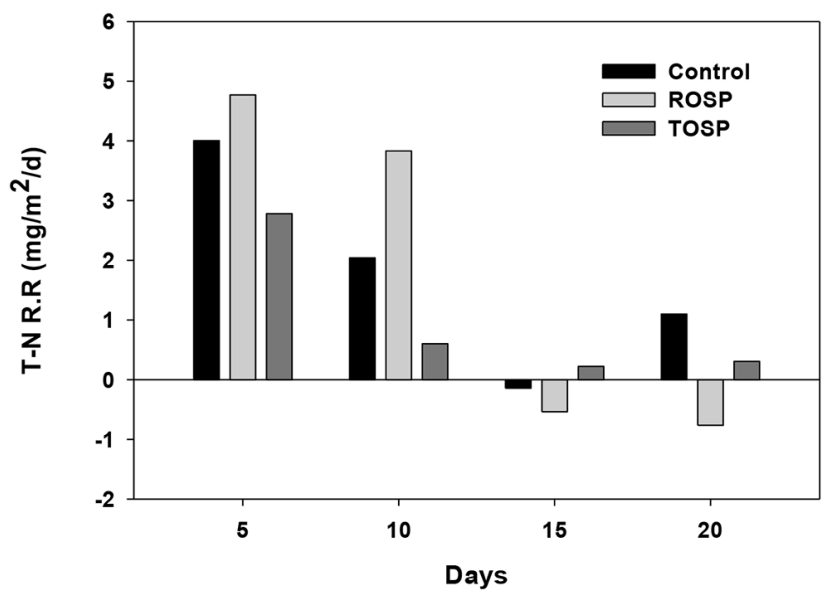

Fig. 8. Release rates of total nitrogen $(\mathrm{T}-\mathrm{N})$ from sediments by addition of ROSP, TOSP $(0.5 \% \mathrm{w} / \mathrm{w})$ and control for $20 \mathrm{~d}$.

or even higher if the cells are using ammonium rather than nitrate in the presence of high ammonium concentration as reported [25]. Correlations between algal bloom and ammonium along with OSPs are given in the following section.

Nitrate is the most stable form of inorganic nitrogen in the oxygenated waters. Fig. 7 shows the change of $\mathrm{NO}_{3}^{-}-\mathrm{N}$ concentration with time both in the water phase and sediments. Overall the plots are showing the reduction of nitrate in the control and ROSP treated basins, which implies no significant nitrifying bioreactions in those basins. It rather suggests biological denitrification or shifted chemical equilibrium between oxidized ions and ammonium ions. However, nitrate remained constant or even higher with TOSP treatment. The nitrite nitrogen concentration is very low and continuously decreased, which became negligible [27]. Even if ammonium is liberated, the remnant portion in the water phase is apt to confront free oxygen molecules released from the peroxide of treated shell particles, thus leading to nitrate/nitrite formation with aid of nitrifying bacteria or direct oxidation. On the other hand, nitrate migration from the sediment was found to be trivial (see the curve slopes in Fig. 7(b)), the environment around the sediment remained anoxic or anaerobic (rare oxidized molecules) for the most of test times. Because of the initial ORP was -215.3 $\mathrm{mV}$ in the sediment, which confirmed a highly anoxic state in all basins.

The concentration changes of $\mathrm{T}-\mathrm{N}, \mathrm{NH}_{4}{ }^{+}-\mathrm{N}$, and $\mathrm{NO}_{3}{ }^{-}-\mathrm{N}$ in the water and sediment phases were assumed to be coupled or interrelated to $\mathrm{pH}, \mathrm{DO}$, and chlorophyll-a as deducted from our experimental scheme. The nutrients released from sediments and water are affected by many factors, such as oxygen condition, bioturbation, $\mathrm{pH}$ and temperature [28]. Summarizing every test made in this work confirmed a certain, positive impact of DO on the diminishment of eutrophication in the saline water. DO was provided by TOSP particles in order to initiate and activate bioaugmentation accordingly. In particular, that excess DO could help to catalyze nitrification and/or denitrification processes [29] to reduce several nitrogenous species including total nitrogen. Consequently, anaerobic conditions in the sediment and higher level of DO in the water phase were said to be responsible for the release and holdup of ammonium [30, 31].

\subsection{Evaluation of Release Rates from Sediments to Water}

Nitrogen is a predominant substance in terms of its influence on biological activity and its migration between the bottom and the water column. The exchanges of nutrients between sediment and water are highly complex, involving physical, interrelated chemical and biological processes [32]. For simplicity, using a method of Hieltjes and Lijklema [22], T-N release rates were calculated as shown in (Fig. 8).

Nutrients releases to the bulk water were active in the first $10 \mathrm{~d}$ and reduced to some trivial scale in $20 \mathrm{~d}$. ROSP treatment did not blocked the migration of nitrogen and even caused a reverse migration (bulk to bottom) meanwhile TOSP treatment successfully blocked that migration by $86 \%$ compared to the very early stage. On the other hand, the natural attenuation (control) was about $50 \%$ in $10 \mathrm{~d}$. 


\section{Conclusions}

The remediation ability of OSPs was studied through the evaluation of COD, nitrogenous compounds, and nutrient release fluxes. Test efficacy of those treatments was found through monitoring of DO and $\mathrm{pH}$ in the controlled environment. Based on the results obtained in this study, it can be concluded that: 1) TOSP could be useful for increasing oxygen level (i.e., peroxide) of sediments and water as a compound for the release of oxygen. 2) The algal growth in the saline water was reduced with the application of TOSP and also significantly reduced nitrogen compounds such as ammonium, total nitrogen and slightly increased nitrate/nitrite, probably due to the facilitation of microbial degrading activity both in overlying water and bottom sediment. The treated compound has also shown its effectiveness on the repression of algal growth owing to blockage of nitrogen source migrating from the sediment. 3) OSPs have proved their absorbing capacity for organic/inorganic matter and well-balanced sustain of alkalinity and ecological systems in the saline water. Overall, TOSP proves its great potential to physical and chemical remediation in the organically enriched sediments and effective for the control of eutrophication.

\section{Acknowledgments}

This research was supported by Basic Science Research Program through the National Research Foundation of Korea (NRF) funded by the Ministry of Science, ICT \& Future Planning (2017R1A 2B4008720) and BK21 plus program, South Korea. Also, we do thank Soonchunhyang University for supporting a MS graduate student, Gilsun Yoo through the undergraduate-graduate student's scholarship program.

\section{References}

1. Bužančić M, Ninčević Gladan Ž, Marasović I, Kušpilić G, Grbec B. Eutrophication influence on phytoplankton community composition in three bays on the eastern Adriatic coast. Oceanologia 2016;58:302-316.

2. Schumacher J, Dolch T, Reise K. Transitions in sandflat biota since the 1930s: Effects of sea-level rise, eutrophication and biological globalization in the tidal bay Konigshafen, northern Wadden Sea. Helgol. Mar. Res. 2014;68:289-298.

3. Glibert PM, Burkholder JM. Harmful algal blooms and eutrophication: Strategies for nutrient uptake and growth outside the Redfield comfort zone. Chinease J. Oceanol. Limnol. 2011;29: 729-738.

4. Nagasoe S, Shikata T, Yamasaki Y, et al. Effects of nutrients on growth of the red-tide dinoflagellate Gyrodinium instriatum Freudenthal et Lee and a possible link to blooms of this species. Hydrobiologia 2010;651:225-238.

5. Jayaweera M, Asaeda T. Impacts of environmental scenarios on chlorophyll-a in the management of shallow, eutrophic lakes following biomanipulation: An application of a numerical model. Ecol. Eng. 1995;5:445-468.
6. Guinder VA, López-Abbate MC, Berasategui AA, et al. Influence of the winter phytoplankton bloom on the settled material in a temperate shallow estuary. Oceanologia 2015;57:50-60.

7. Carpenter SR, Caraco NF, Correll DL, Howarth RW, Sharpley AN, Smith VH. Nonpoint pollution of surface waters with phosphorus and nitrogen. Ecol. Applic. 1998;8:559-568.

8. Kwon H-B, Lee C-W, Jun B-S, Yun J-D, Weon S-Y, Koopman B. Recycling waste oyster shells for eutrophication control. Resour. Conserv. Recy. 2004;41:75-82.

9. Nakatani N, Takamori H, Takeda K, Sakugawa H. Transesterification of soybean oil using combusted oyster shell waste as a catalyst. Bioresour. Technol. 2009;100:1510-1513.

10. Park WH, Polprasert C. Roles of oyster shells in an integrated constructed wetland system designed for P removal. Ecol. Eng. 2008;34:50-56.

11. Yoon GL, Kim BT, Kim BO, Han SH. Chemical-mechanical characteristics of crushed oyster-shell. Waste Manage. 2003;23: 825-834.

12. Lee CH, Lee DK, Alia MA, Kima PJ. Effects of oyster shell on soil chemical and biological properties and cabbage productivity as a liming materials. Waste Manage. 2008;28:2702-2708.

13. Liu SJ, Jiang B, Huang G-Q, Li X-G. Laboratory column study for remediation of MTBE-contaminated groundwater using a biological two-layer permeable barrier. Water Res. 2006;40: 3401-3408.

14. Hanh D, Rajbhandari B, Annachhatre A. Bioremediation of sediments from intensive aquaculture shrimp farms by using calcium peroxide as slow oxygen release agent. Environ. Technol. 2005;26:581-589.

15. Cassidy DP, Irvine RL. Use of calcium peroxide to provide oxygen for contaminant biodegradationina saturated soil. $J$. Hazard. Mater. 1999;69:25-39.

16. Nykänen A, Kontio H, Klutas O, et al. Increasing lake water and sediment oxygen levels using slow release peroxide. Sci. Total Environ. 2012;429:317-324.

17. Lee HS, Park DW, Woo DS. A study on physicochemical and calcination processed characteristic of oyster shell. J. Korea Acad. Ind. Cooper. Soc. 2009;10:3971-3976.

18. Huh J-H, Choi Y-H, Lee H-J, et al. The use of oyster powders for water quality improvement of lakes by algal blooms removal. J. Korean Ceram. Soc. 2016;53:1-6.

19. Standard method for the examination of sea water and sediment. Ministry of Oceans and Fisheries, South Korea. 2013.

20. Hieltjes AH, Lijklema L. Fractionation of inorganic phosphates in calcareous sediments. J. Environ. Qual. 1980;9:405-407.

21. Cho D, Jiang S, Kwon SH. Chemical and biological analyses of bay sediment where magnesium oxide compounds are applied. Environ. Eng. Res. 2014;19:101-105.

22. Kaya K, Liu YD, Shen YW, Xiao BD, Sano T. Selective control of toxic Microcystis water blooms using lysine and malonic acid: An enclosure experiment. Environ. Toxicol. 2005;20:170-178.

23. Scholz M. Wetland systems to control urban runoff. 1st ed. Amsterdam: Elsevier Science; 2006.

24. Smith VH. Low nitrogen to phosphorus ratios favour dominance by blue-green algae in lake phytoplankton. Science 1983;221: 669-671.

25. Dugadale RC, Wilkerson FP, Hogue VE, Marchi A. The role of ammonium and nitrate in spring bloom development in 
San Francisco Bay. Estuar. Coast. Shelf Sci. 2007;73:17-29. 26. Xiang S-L, Zhou W-B. Phosphorus forms and distribution in the sediments of Poyang Lake, China. Int. J. Sediment Res. 2011;26:230-238.

27. Wu Q, Zhang R, Huang S, Zhang H. Effects of bacteria on nitrogen and phosphorus release from river sediment. $J$. Environ. Sci. 2008;20:404-412.

28. Boström B, Andersen JM, Fleischer S, Jansson M. Exchange of phosphorus across the sediment water interface. Hydrobiologia 1988;170:229-244.

29. Stolp H. Microbiological ecology: Organisms, habitats, activities. Cambridge Univ. Press; 1988.
30. Beutel MW. Inhibition of ammonia release from anoxic profundal sediments in lakes using hypolimnetic oxygenation. Ecol. Eng. 2006;28:271-279.

31. Beutel MW, Leonard TM, Dent SR, Moore BC. Effects of aerobic and anaerobic conditions on $\mathrm{P}, \mathrm{N}, \mathrm{Fe}, \mathrm{Mn}$, and $\mathrm{Hg}$ accumulation in waters overlaying profundal sediments of an oligo-mesotrophic lake. Water Res. 2008;42:1953-1962.

32. Hou D, He J, Lü C, Sun Y, Zhang F, Otgonbayar K. Effects of environmental factors on nutrients release at sediment-water interface and assessment of trophic status for a typical shallow lake, Northwest China. Sci. World J. 2013;2013:articleID716342. 